\section{CF screening premature?}

\section{Washington}

Aт its annual meeting last week in Baltimore, Maryland, the American Society for Human Genetics (ASHG) issued a statement urging caution in the use of screening tests to alert couples to the presence of a genetic defect associated with cystic fibrosis (CF) and the consequent possibility that their children might be born with the disease. Geneticists agree that testing should be offered when either partner has a close relative affected with $\mathrm{CF}$, but say they have "serious reservations" about widespread screening.

The race to develop a new test was prompted by the announcement in August of the cloning of the gene for CF by researchers at the University of Michigan, the University of Toronto and the Hospital for Sick Children, Toronto (see Science 245, 1059; 1989). Before then, CF could be detected only using conventional linkage analysis, which was available only to those with a family history of CF and with an affected relative still living. The discovery of the genetic mutation meant that a quick and cheap test could be developed based on a DNA probe specific for the mutation.

But the new test can still detect only about 70 per cent of CF carriers, because only that proportion of victims of CF have the identified mutation. Some researchers say that there should be no widespread screening for $\mathrm{CF}$ until the identification of additional mutations, which is expected within a year; others argue that the test is valuable despite its shortcomings and that widespread screening is worthwhile.

At its meeting last week, the ASHG HUMAN FRONTIER PROGRAM - -

\section{Strasbourg office opens}

Tokyo

THE long-awaited opening of the office for Japan's Human Frontier Science Program in Strasbourg, France was due to take place on Tuesday, 21 November (see Nature 340, 329; 1989). As of 17 November, more than 130 research groups led by scientists from the seven summit nations (Japan, United States, Canada, Britain, West Germany, France and Italy) and the European Communities had applied for the 20 or so $\$ 500,000$ grants that will be available, for research on the brain and molecular recognition, in the first year of full operation of the programme. Because of delays in opening the office in Strasbourg, the deadline for grant, fellowship and workshop applications will be extended to the end of this month, according to Toichi Sakata, director of the Frontier office at the Science and Technology Agency. erred on the side of caution, saying general screening should wait until a larger proportion of CF carriers can be detected and also until there is a better idea of the education and counselling that could be given to CF carriers. To this end, says the ASHG, pilot screening programmes should be started as soon as possible. Peter Lanciano, the general manager of Integrated Genetics Inc., one of the companies providing a $\mathrm{CF}$ test, endorsed the ASHG statement, saying that it would do a disservice to the public to rush ahead with widespread screening "just because you can do part of the work".

He said that the company will refuse to provide the test to anyone who does not have a family history of CF. Frank Fujimura, scientific director of molecular biology at the Nichols Institute said that the institute would advise against taking the test but would not refuse it. But he admitted that resources are not available for providing counselling services on the scale required for routine widespread carrier screening for $\mathrm{CF}$.

Fujimara said that although the laboratories involved are highly regarded, there is widespread concern at the lack of mechanisms to ensure that standards are maintained. In last week's statement, the ASHG also called for centralized quality control; both it and the College of American Pathologists are considering some kind of certification procedure for laboratories. The ASHG is now establishing a working group to study all the issues raised by the new test and produce a report next year. Christine McGourty BIOTECHNOLOGY

\section{Celltech to change hands?}

\section{London}

THE major shareholder in Celltech, the largest UK biotechnology company, is to sell its 36.4 per cent holding. It is considered likely that potential buyers will bid for all of Celltech's shares.

British and Commonwealth Holdings has been a shareholder from the start of Celltech in 1980. It has decided to sell its shares for "strategic reasons", and has asked the board of Celltech to identify possible buyers.

The news follows an announcement by chief executive Gerard Fairtlough, that he is to stand down from the company he has led from the start. Celltech, best known for its monoclonal antibody products, recorded its first profitable year in 1987. Last year was also marginally profitable.

Peter Newark

\title{
Limited use approved in India
}

\section{Bangalore}

INDIA's National Monitoring Agency (NMA), set up by the government to study the problems associated with food irradiation, has approved limited irradiation tests with a view to general commercial use of the process, which kills bacteria that cause deterioration of food. Food irradiation became controversial in India following public protests over the import by India of Irish butter-oil that was alleged to have been contaminated by fallout from the Chernobyl nuclear explosion.

But now M.R. Srinivasan, chairman of India's Atomic Energy Commission, says that the NMA has approved the irradiation of spices and frozen sea food for export, as well as the irradiation of onions for the home market. To further the prospects of commercialization, the Department of Atomic Energy has joined with Gujarat Agro Industries Corporation and the Spices Board of Kerala, and intends soon to set up gamma irradiation facilities in a number of places in India.

Radhakrishna Rao

\section{SOUTH AFRICA- Rach \\ New CSIR president}

\section{Cape Town}

DR Brian Clark, 41, has been appointed president-elect of the South African Council for Scientific and Industrial Research (CSIR). The appointment was announced earlier this month by the Minister of Trade, Industry and Tourism, Mr Kent Durr. Clark will succeed Dr Chris Carberts, the current CSIR president, in September next year. He will be the sixth and youngest president of the organization, which is the largest of South Africa's three major research councils.

Clark joined the council's National Physical Research Laboratory as a technician after leaving school in 1965, and completed both his undergraduate and postgraduate training at the University of Pretoria as a part-time student.

Clark's present post in the CSIR is executive head of research, development and implementation (RDI). In this capacity he has been responsible for leading last year's restructuring of the organization into 12 technologically orientated divisions in the hope of attracting more research contracts from the private sector and government departments (See Nature $332,197 ; 1988)$. In the current financial year, he expects outside contracts to amount to R174 million, accounting for 55 per cent of the RDI's budget.

Clark said in a statement that he hoped "to manage the CSIR in such a way as to make a major contribution to the ongoing development of South Africa".

Michael Cherry 